\title{
$\angle$ Research Square on
}

\section{A First Comparison of Microplastics Abundance between Two Whale Shark Feeding Areas of the Gulf of California, Mexico.}

\section{Lara Roberta Cardelli}

Instituto Politécnico Nacional Centro Interdisciplinario de Ciencias Marinas: Instituto Politecnico Nacional Centro Interdisciplinario de Ciencias Marinas

Francesca Pancaldi ( $\nabla$ frampi@gmail.com ) Instituto Politécnico Nacional Centro Interdisciplinario de Ciencias Marinas: Instituto Politecnico Nacional Centro Interdisciplinario de Ciencias Marinas https://orcid.org/0000-0003-4132-5402

\section{Felipe Galván Magaña}

Instituto Politécnico Nacional Centro Interdisciplinario de Ciencias Marinas: Instituto Politecnico Nacional Centro Interdisciplinario de Ciencias Marinas

\section{Darren Andrew Whitehead}

pelagios kakunjá

\section{Research Article}

Keywords: endangered species, Gulf of California, contamination, microplastics, ingestion rate, whale shark

Posted Date: June 15th, 2021

DOI: https://doi.org/10.21203/rs.3.rs-567472/v1

License: (c) (1) This work is licensed under a Creative Commons Attribution 4.0 International License. Read Full License 


\section{Abstract}

Abundance and typology of microplastics (MPs) were measured in 12 water samples collected from two whale sharks feeding areas of the Gulf of California (Bahía de los Angeles (BLA) and Bahia de La Paz (LAP)). The concentration of MPs was $0.47 \mathrm{MPs} / \mathrm{m}^{3}$ in BLA and $0.63 \mathrm{MPs} / \mathrm{m}^{3}$ in LAP. Overall, films were the most abundant type of MPs $(41 \% ; n=74)$ followed by line $(37 \% ; n=68)$, fragments $(20 \% ; n=36)$ and pellet $(2 \% ; n=3)$, with significative differences between the types of microplastics. Theoretical ingestion rate per hour of MPs for the species was determined to be 288.58 and 386.82 in BLA and LAP, respectively. In faecal samples collected directly from animals of LAP $(n=3), 67 \%$ of the MPs were films, $25 \%$ were fragments, and $8 \%$ were lines. Results from this study indicate that MPs are common in the feeding areas of this endangered species and that whale sharks are likely ingesting MPs from filtering the surface water.

\section{Main Text}

Plastic pollution is a serious global threat in marine ecosystems (Villarrubia-Gómez et al. 2018). Anthropogenic activities such as poorly manage waste from urban site, aquaculture and fishing are increasingly responsible for the offload of plastics debris in the oceans (Rochman et al. 2013). It is estimated between 6 and 12 tons of plastics end up in the oceans every year (Jambeck et al. 2015). Once in the marine environment, these pollutants travel long distances and eventually (through mechanical, chemical, or biological processes) break down in microplastics (MPs), defined as plastics $<5 \mathrm{~mm}$ in diameter (Andrady 2011). Because of their small size, MPs are up taken by different organisms including microalgae (Zhang et al. 2017), zooplankton (Cole et al. 2013), teleost fish (Lusher et al. 2013) and megafauna (Fossi et al. 2017; Germanov et al. 2018). Consequences of these ingestions often include toxics effects (Zhang et al. 2017), gastrointestinal blockage, starvation, and death (Wright et al. 2013).

Filter feeder species are particularly vulnerable to MPs (Fossi et al. 2017; Germanov et al. 2019; Pennino et al. 2020). The whale shark, Rhincodon typus (Smith 1828) is the largest fish of the planet (Compagno 2001); it is a filter feeder with long life span and a circumglobal distribution (Stevens 2007; Rowat and Brooks 2012). In the Gulf of California, Mexico, feeding aggregations of whale shark are seasonally spotted in Bahía de los Angeles (Nelson and Eckert 2007) and Bahía de La Paz (Ketchum et al., 2013), where animals are seen feeding on dense patched of copepods, quetognats, and eufausids (Whitehead et al. 2019). Internationally, whale sharks are listed as "Endangered" by the International Union for the Conservation of Nature red list and in Mexico this species is protected under two national laws (DOF 2006 , 2010). The presence of whale shark feeding aggregations in Bahia de los Angeles and Bahia de La Paz over the last two decades has risen to intense tourist activities and now represents an important economic source for the local community. In these areas, the increasing tourist pressure has forced local authorities to enforce management plans to guarantee the safety and conservation of the animals (SEMARNAT 2017). 
Despite these measures, recent studies have showed that whale sharks from Bahía de La Paz are exposed to toxic substances such as heavy metals (Pancaldi et al. 2019 a,b), persistent organic pollutants and plastic pollution (Fossi et al. 2017) as a result of continuous feeding activity on the sea surface near costal urban areas. The aim of this study is to provide the first analysis of the abundance and type of MPs present in the surface waters in two whale sharks feeding areas of the Gulf of California (Bahía de los Angeles (BLA) and Bahia de La Paz (LAP)) during the period of maximum presence of the sharks in these areas. Analysis of MPs was also performed in faecal samples collected directly from animals in LAP.

Tows of water were performed in September 2016 in "La Mona” area, south of Bahía de los Angeles (BLA; $28.9519^{\circ} \mathrm{N}, 113.5624^{\circ} \mathrm{W}$; Fig. 1) and from October to December 2016 in the "Mogote" area, south of Bahía de La Paz (LAP; $24.0832^{\circ} \mathrm{N}, 110.1839^{\circ} \mathrm{W}$; Fig. 1). A manta net with a mesh of $333 \mu \mathrm{m}, 43.5 \mathrm{~cm}$ long and $14 \mathrm{~cm}$ wide was used to perform water tows. Tows were performed during the presence of foraging whale sharks, with wind speed between 2.5 and 7 knots. Whale shark presence was assessed visually and the estimation of total length ( $T L$ ) of the individuals was established using an object (e.g., swimmer, boat) for comparison. Tows were trailed for 10 minutes at 2 knots, in a lineal path, parallel to the sharks' movement. Once the net was recovered, the material was placed in a glass baking dish and subsequently stored in an additional glass storage jar. To avoid any possible contamination from plastic, the cap of the jar was covered with an aluminium foil before closing, then frozen at $-20^{\circ} \mathrm{C}$ for ahead of microscope analysis.

Samples were unfrozen, moved into aliquots in a Petri dish and observed with a microscope Carl Zeiss model Stemi DV4. The particles, recognized morphologically as microplastics, were recovered with sterile tweezers, and placed in storage with cover glass objects. The microplastics were divided into 4 different classes of shape: fragment, line, pellet, and film (Rochman et al. 2013; Lorenzo- Navarro et al. 2018; Germanov et al. 2019). A "fragment" was considered as a piece of hard plastic with undetermined margin line (Fig. 2a); a "line" was considered a MP with elongated, cylindrical shape and high flexibility (Fig. 2b); a "pellet" was considered a compressed piece with a typical spheric shape (Fig. 2c); and a "film" was a thin and flexible piece with undetermined margin line (Fig. 2d). To avoid contamination, samples observation was performed in a sterilized room and above a fume hood (Choy and Drazen 2013; Avio et al. 2015).

The total volume of analysed water in each area was calculated by multiplying the length of the examined surface (distance between GPS start point and GPS end point of the trawling) and the area of the manta net mouth (which is calculated as the long side multiplied the short side) expressed in $\mathrm{m}^{3}$. To know the concentration of MPs per $\mathrm{m}^{3}$ found in each area, the total number of MPs was divided by the total volume of water analysed.

Faecal samples were collected in November 2016 in LAP (Mogote area; Fig. 1). Feces, identified as compact brownish to reddish material, were collected from a swimmer during opportunistic field observations after being defecated by the shark. The samples were collected in crystal jars and initially 
stored on ice packs, then transferred to long-term storage at $-20^{\circ} \mathrm{C}$ before analyses. Samples were contained less than a minute after being defecated by the shark, nevertheless, environmental contamination from microplastics may have occurred when they were collected from the water.

Whale shark theoretical MPs ingestion rates were calculated based on filtration volumes of captive whale shark individuals from the Georgia Aquarium and for free swimming animals based on the data published by Motta et al. (2010). As data followed a normal distribution, parametric tests were applied to the results.

A total of 12 water samples were collected: 5 in BLA and 7 in LAP. A total volume of $143.674 \mathrm{~m}^{3}$ was analysed in BLA and $190.01 \mathrm{~m}^{3}$ in LAP. In BLA a total of 27 whale sharks were observed during the sampling collections and 19 whale sharks were observed in LAP. Average total length (TL) of sharks was $6.2 \mathrm{~m}$ for BLA and $5.4 \mathrm{~m}$ for BLP. In BLA $61 \mathrm{MPs}$ were encountered in the collected water (10 in the sample \#1, 11 in the sample \#2, 15 in the sample \#3, 13 in the sample \#4 and 12 in the sample \#5; Table 1) and in LAP 120 MPs were reported (15 in the sample \#1, 7 in the sample \#2, 21 in the sample \#3, 14 in the sample \#4, 21 in the sample \#5, 29 in the sample \#6 and 13 in the sample \#7; Table 1). The concentration of MPs was $0.47 \mathrm{MPs} / \mathrm{m}^{3}$ in BLA and $0.63 \mathrm{MPs} / \mathrm{m}^{3}$ in LAP. No significant differences were found between the number of MPs found in each site.

Table 1. Number of MPs found in water samples collected in BLA and LAP.

\begin{tabular}{lcccccc}
\hline Site & Sample & Fragment & Line & Pellet & Film & Total \\
\hline BLA & 1 & 0 & 3 & 0 & 7 & 10 \\
& 2 & 3 & 4 & 0 & 4 & 11 \\
\hline & 3 & 4 & 6 & 0 & 5 & 15 \\
\hline & 4 & 3 & 8 & 0 & 2 & 13 \\
\hline & 5 & 2 & 4 & 0 & 6 & 12 \\
\hline LAP & & 12 & 25 & 0 & 24 & 61 \\
\hline & 1 & 0 & 6 & 0 & 9 & 15 \\
\hline & 2 & 0 & 5 & 1 & 1 & 7 \\
\hline & 3 & 5 & 9 & 0 & 7 & 21 \\
\hline & 4 & 5 & 3 & 2 & 4 & 14 \\
\hline & 5 & 4 & 8 & 0 & 9 & 21 \\
\hline & 6 & 3 & 11 & 0 & 15 & 29 \\
\hline & 7 & 7 & 1 & 0 & 5 & 13 \\
\hline Total of two bays & & $36^{a, b, c}$ & $68^{a, d}$ & $5^{\mathbf{b}, \mathrm{d}, \mathbf{e}}$ & $74^{c, \mathbf{e}}$ & 181 \\
\hline & & & & & & \\
\hline
\end{tabular}

Subscription letters indicate significative differences between type of MPs. Italic letters indicate $p$ Student $t$-test $<0.05$, bold letters indicate $p$ Student $t$-test $<0.001$. Statistic tests were performed using Statistica software.

Considering both study areas together ( $n$ tows $=12), 41 \%$ of MPs were films $(n=74), 37 \%$ line $(n=68)$, $20 \%$ fragments $(n=36)$ and $2 \%$ pellet $(n=3)$. Fig. 3. Student $t$-test indicated significative differences 
between the number of fragments and pellet, line and pellet, film, and pellet $(P<0.001$; Table 1$)$, fragments and line and fragments and film $(P<0.05$; Table 1$)$. In BLA $44 \%$ of the total MPs found were films ( $n=24), 38 \%$ line $(n=25), 18 \%$ fragments $(n=12)$ and no pellets were found (Fig. 3). In LAP $42 \%$ of the total MPs found were films $(n=50), 36 \%$ lines $(n=43), 20 \%$ fragments $(n=24)$ and $2 \%$ pellet $(n=3$; Fig. 3). No significant differences were found between the MPs shape per site.

Three faecal samples were collected from three different specimens in Bahia de La Paz. Faecal sample \# 1 showed a total of 3 MPs (all films), faecal sample \#2 showed 5 films and 1 line, while faecal sample \#3 showed 3 MPs (all fragments). In total, $67 \%$ of the MPs found in the faecal samples were films, $25 \%$ fragments and $8 \%$ lines.

Theoretical ingestion rate for whale sharks from BLA and LAP was calculated based on data published by Motta et al. (2010) which showed that a $622 \mathrm{~cm}$ whale shark from the Georgia Aquarium, Atlanta, can filter $614 \mathrm{~m}^{3}$ of water per hour. According to these data, whale sharks from this study can ingest 288.58 and $386.82 \mathrm{MPs} / \mathrm{h}$ in BLA and LAP, respectively. Considering that whale sharks from the Gulf of Mexico feeds during 7.5 hours per day (Motta et al. 2010) the theoretical ingestion rate per day in the sharks from BLA would be 2164.35 MPs / day and 2901.15 MPs / day in LAP.

Microplastics (MPs) were found in water samples and faecal samples indicating that these pollutants are present in the feeding areas of this endangered species and that whale sharks are likely ingesting MPs from filtering the surface water. In the water trawls, the number of MPs found in the total volume of water analysed $\left(B L A=0.47 \mathrm{MPs} / \mathrm{m}^{3} ; \mathrm{LAP}=0.63 \mathrm{MPs} / \mathrm{m}^{3}\right)$ was higher than what was observed by Fossi et al. (from 0.00 items $\mathrm{m}^{3}$ to 0.14 items per $\mathrm{m}^{3}$; Fossi et al. 2017). The number of MPs per $\mathrm{m}^{3}$ from this study were in the same range of concentration of what was found by Germanov et al. 2019 ( 0.56 to 0.90 pieces $\mathrm{m}^{3}$ ) during trawl surveys performed in whale shark and the reef manta ray Mobula alfrediforaging area in Indonesia during the wet season. Indonesia contributes to about $14 \%$ of the global annual plastic pollution in the marine environment (Lebreton et al. 2017; Germanov et al. 2019) with highest input recorded during the wet season compared to the dry one (Germanov et al. 2019). Similarly, a significant quantity of plastics debris is also found in a similar foraging area Bahia de Banderas, Mexico, during the wet season due to river inputs (Pelamatti et al. 2019).

Despite that significative differences were not found (probably because of the low sample size), water collected from LAP showed higher concentration of MPs per $\mathrm{m}^{3}$ compared to BLA. The whale shark feeding area of Bahia de La Paz (Mogote area; Fig. 1) is located in close proximity to the city of La Paz, the second most inhabitant city of Baja California Sur (272.211 habitants recorded in 2015; INEGI; http://cuentame.inegi.org.mx/monografias/informacion/bcs/poblacion/default.aspx?tema=me\&e=03). In addition, the whale shark feeding aggregation season in Bahía de La Paz coincides with the period of strong north wind that could potentially accelerates the influx of plastic debris from the urban area to the adjacent foraging area of the sharks. 
Considering both study areas, film was the MPs with the highest incidence followed by line, fragments, and pellet. Films were also the main MPs shape found in the whale shark feces collected in LAP, which confirms the high presence of these pollutants and the risks associated to them. Pellet was the MPs with a significantly lower incidence than the other types $(P<0.001)$. Pellets are primary MPs (Barnes et al. 2009) used mainly in cosmetic, pharmaceutical and textile industry (Gregory 1996; Fendall and Sewell 2009).

Considering that neither La Paz nor Bahia de los Angeles are industrial cities, it is probable why pellets showed such low incidence compared to the other MPs shapes. On the contrary, film, fragment and line are secondary MPs (Barnes et al. 2009) derived from the breakup of daily use products (cloths, plastic bags, bottles, fishing gears) and, in our study areas they are likely to ended up on local beaches and/or washed by currents into the whale shark feeding areas. Daily theoretical ingestion rate for whale sharks from this study was higher (2164.35 MPs / day in BLA, and 2901.15 MPs / day in LAP) compared to a previous study performed in Bahía de La Paz (171 MPs / daily; Fossi et al. 2017) and to another study performed in Indonesia (326 MPs / h; Germanov et al. 2019). Risks associated with ingestion of plastic debris by megafauna include possible toxic effects provoked by the presence of plastic associated pollutants such as organochlorine compounds and heavy metals (Fossi et al. 2017; Pancaldi et al. $2019 a, b)$. The latter ones have been previously detected in skin biopsies of feeding whale sharks from Bahía de La Paz (Pancaldi et al. 2019a) and organs of stranded whale sharks from Bahía de La Paz and Punta Bufeo (Pancaldi et al. 2019b), even if this contamination has not been linked to exposure through plastic ingestion. On the contrary, organochlorine compounds (PCBs, DDTs), and polybrominated diphenyl ethers (PBDEs) plastic additives associated to plastic materials has been detected in skin biopsies of whale sharks from La Paz Bay (Fossi et al. 2017).

In conclusion, the presence of microplastics in whale shark feeding areas represents a threat to whale sharks which uptake these items by continuously filter feeding on the water surface. Local policies that regulate the use of plastic items should be enforced especially in areas adjacent to feeding grounds of protected megafauna. Further research should be carried out to evaluate the risks related to the ingestion of microplastics in this endangered species.

\section{Declarations}

- Ethics approval and consent to participate

This study was performed on a protected species under the Secretaría del Medio Ambiente y Recursos Naturales (SEMARNAT) permit number: SGPA/DGVS 05605/17. No animal was killed during this study

- Consent for publication

Not applicable

- Availability of data and materials 
All data generated or analysed during this study are included in this published article [and its supplementary information files].

- Competing interests

The authors declare that they have no competing interests.

- Funding

Comisión de Operación y Fomento de Actividades Académicas (COFAA) fellowship: collection and analysis of data

Education Department Costa Edutainment Spa: collection and analysis of data

Centro Interdisciplinario de Ciencias Marinas (CICIMAR) Project "Tiburones y Rayas" and "Cambios estacionales de las presas zooplanctónicas clave del tiburón ballena Rhincodon typus en Bahía de La Paz, B.C.S.". Grant number SIP: 20170585 and to the SIP-IPN Proyect "Ecología trófica de los tiburones de la costa occidental del Golfo de California". Grant number SIP: 20181417: collection and analysis of data

\section{- Author's contributions}

Lara R. Cardelli: Formal analysis; Writing - review \& editing; Methodology; Field work. Francesca Pancaldi: Conceptualization; Data curation; Formal analysis; Software; Writing - Original draft; Writing - review \& editing; Visualization. Felipe Galván Magaña: Funding acquisition; Project administration; Resources; Supervision; Writing - review \& editing; Validation. Darren A. Whitehead: Investigation; Writing- review.

- Acknowledgements

We would like to thank Dr. Stefano Furlati from the Education Department Costa Edutainment Spa for the donation of the field material. Thanks to the Instituto Politécnico Nacional for the support received through the -Contracting Excellence Program- and Fellowship EDI and COFAA. Thanks to CICIMAR Project "Tiburones y Rayas" and "Cambios estacionales de las presas zooplanctónicas clave del tiburón ballena Rhincodon typus en Bahía de La Paz, B.C.S.”. Grant number SIP: 20170585.

\section{References}

1. Andrady AL (2011) Microplastics in the marine environment. Mar Pollut Bull 62 1596-1605. doi: 10.1016/j.marpolbul.2019.02.030

2. Avio CG, Gorbi S, Regoli F (2015) Experimental development of a new protocol for extraction and characterization of microplastics in fish tissues: First observations in commercial species from Adriatic Sea. Mar Environ Res 111 18-26. https://doi.org/10.1016/j.marenvres.2015.06.014

3. Barnes DKA, Galgani G, Thompson RC, Barlaz M (2009) Accumulation and fragmentation of plastic debris in global environments. Philos Trans R Soc Lond B, 364, 1985-1998. 
https://doi.org/10.1098/rstb.2008.0205

4. Choy CA, Drazen JC (2013) Plastic for dinner? Observations of frequent debris ingestion by pelagic predatory fishes from the central North pacific. Mar Ecol Prog Ser $485155-$

163. https://doi.org/10.3354/meps 10342

5. Cole M, Lindeque P, Fileman E, Halsband C, Goodhead R, Moger J, Galloway TS (2013) Microplastic ingestion by zooplankton. Environ Sci Technol 47 6646-6655. doi: 10.1021/es400663f

6. Compagno LJV (2001) Sharks of the world, an annotated and illustrated catalogue of shark species known to date. FAO Species Catalogue for Fishery Purposes, No 1, Volume 2. Rome: FAO. https://doi.org/10.1002/iroh.19870720329

7. DOF (2006) NOM 029-PESC-2006. Responsible fishing for sharks and rays, Specifications for their use. In Spanish.

8. DOF 2010, NOM 059 SEMARNAT 2010. Environmental protection of native Mexican species of wild flora and fauna. Risk categories and specifications for their inclusion, exclusion or change. List of species at risk. In Spanish.

9. Fendall LS, Sewell MA (2009) Contributing to marine pollution by washing your face: microplastics in facial cleansers. Mar Poll Bull 58 1225- 1228. doi:10.1016/j.marpolbul.2009.04.025.

PMID:19481226

10. Fossi MC, Baini M, Panti C, Galli M, Jiménez B, Muñoz-Arnanz J, Marsili L, Finoia MG, RamírezMacías D (2017) Are whale sharks exposed to persistent organic pollutants and plastic pollution in the Gulf of California (Mexico)? First ecotoxicological investigation using skin biopsies. Comp Biochem Physiol C, 19: 48-58. doi: https://doi.org/10.1016/j.cbpc.2017.03.002.

11. Germanov ES, Marshall AD, Bejder L, Fossi MC, Loneragan NR (2018) Microplastics: No Small Problem for Filter-Feeding Megafauna. Trends Ecol Evol, 33 (4) 227-232. https://doi.org/10.1016/j.tree.2018.01.005

12. Germanov ES, Marshall AD, Hendrawan IG, Admiraal R, Rohner CA, Argeswara J, Wulandari R, Himawan MR, Loneragan NR (2019) Microplastics on the menu: plastics pollute Indonesian manta ray and whale shark feeding grounds. Front Mar Sci 6:679. 10.3389/fmars.2019.00679

13. Gregory MR (1996) Plastic 'scrubbers' in hand cleansers: a further (and minor) source for marine pollution identified. Mar Pollut Bullet 32:867-871. doi:10.1016/s0025-326x(96)00047-1

14. Jambeck JR, Geyer R, Wilcox C, Siegler TR, Perryman M, Andrady A, Narayan R, Law KL (2015) Plastic waste inputs from land into the ocean. Science 347:768-771. 10.1126/science.1260352

15. Ketchum JT, Galván-Magaña F, Klimley AP (2013) Segregation and foraging ecology of whale sharks, Rhincodon typus, in the southwestern Gulf of California. Environ Biol Fishes 10.1007/s10641-012-0071-9

16. Lebreton LCM, van der Zwet J, Damsteeg JW, Slat B, Andrady A, Reisser J (2017) River plastic emissions to the world's oceans. Nat Commun 8:15611. doi: 10.1038/ncomms15611

17. Lorenzo-Navarro J, Castrillón-Santana M, Gómez M, Herrera A, Marín-Reyes P (2018) Automatic Counting and Classification of Microplastic Particles. In: Proceedings of the 7th International 
Conference on Pattern Recognition Applications and Methods - Volume 1: ICPRAM, ISBN 978-989758-276-9, pages 646-652. Doi: 10.5220/0006725006460652

18. Lusher AL, McHugh M, Thompson RC (2013) Occurrence of microplastics in the gastrointestinal tract of pelagic and demersal fish from the English Channel. Mar Poll Bul 67(1-2):94-9. doi: 10.1016/j.marpolbul.2012.11.028.

19. Motta PJ, Maslanka M, Hueter RE, Davis RL, de la Parra R, Mulvany SL, Habegger ML, Strother JA, Mara KR, Gardiner JM, Tyminski JP, Zeigler LD (2010) Feeding anatomy, filter-feeding rate, and diet of whale sharks Rhincodon typus during surface ram filter feeding off the Yucatan Peninsula, Mexico. Zoology, 113: 199-212. Doi: https://doi.org/10.1016/j.zool.2009.12.001

20. Nelson JD, Eckert SA (2007) Foraging ecology of whale sharks (Rhincodon typus) within Bahía de Los Angeles, Baja California Norte, Mexico. Fish Res 84: 47-64. Doi: https://doi.org/10.1016/j.fishres.2006.11.013

21. Pancaldi F, Galván-Magaña F, González-Armas R, Soto-Jimenez MF, Whitehead DA, O'Hara T, Marmolejo-Rodríguez AJ, Vázquez-Haikin A, Páez-Osuna F (2019a) Mercury and selenium in the filter-feeding whale shark (Rhincodon typus) from two areas of the Gulf of California, Mexico. Mar Poll Bull 146: 955-961. https://doi.org/10.1016/j.marpolbul.2019.07.017.

22. Pancaldi F, Páez-Osuna F, Soto-Jiménez MF, González-Armas R, O'Hara T, Marmolejo-Rodríguez AJ, Vázquez-Haikin A, Galván-Magaña F (2019b) Trace elements in tissues of whale sharks (Rhincodon typus) stranded in the Gulf of California, Mexico. Bull Env Cont Toxi 103 (4): 515- 530. Doi: https://doi.org/10.1007/s00128-019-02640-

23. Pelamatti T, Fonseca-Ponce IA, Rios-Mendoza LM, Stewart JD, Marín Enríquez E, MarmolejoRodríguez, AJ, Hoyos-Padilla EM, Galván-Magaña F, González-Armas R (2019). Seasonal variation in the abundance of marine plastic debris in Banderas Bay. Mexico. Mar Pollut Bull 145, 604-610. doi: 10.1016/j.marpolbul.2019.06.062

24. Pennino MG, Bachiller E, Lloret-Lloret E, Albo-Puigserver M, Esteban A, Jadaud A, Bellido JM, Coll M (2020) Ingestion of microplastics and occurrence of parasite association in Mediterranean anchovy and sardine. Mar Pull Bul 111399. https://doi.org/10.1016/j.marpolbul.2020.111399

25. Rochman CM, Hoh E, Kurobe T, The SJ (2013) Ingested plastic transfers hazardous chemicals to fish and induces hepatic stress. Sci Rep 3, 3263. https://doi.org/10.1038/srep03263

26. Rowat D, Brooks K (2012) A review of the biology, fisheries and conservation of the whale shark Rhincodon typus. J Fish Biol 80 1019-1056. https://doi.org/10.1111/j.1095-8649.2012.03252.x

27. SEMARNAT (2017). Rhincodon typus (whale shark) management plan to carry out non-extractive harvesting activities through observation and swimming in Bahía de La Paz, B.C.S., season 2017. In Spanish. Retrieved from https://www.gob.mx/semarnat/documentos/plan-de-manejo-de-tiburonballena-rhincodon-typus-en-bahia-de-la-paz-bcs

28. Smith A (1828) Descriptions of new, or imperfectly known objects of the animal kingdom, found in the south of Africa. South African Commercial Advertiser, 3, 2 
29. Stevens JD (2007) Whale shark (Rhincodon typus) biology and ecology: a review of the primary literature. Fish Res 84(1):4-9. https://doi.org/10.1016/j.fishres.2006.11.008

30. Villarrubia-Gómez P, Cornell SE, Fabres J (2018) Marine plastic pollution as a planetary boundary threat - The drifting piece in the sustainability puzzle. Mar Policy, 96 213-220. https://doi.org/10.1016/j.marpol.2017.11.035

31. Whitehead DA, Jakes-Cota U, Pancaldi F, Galván-Magaña F, González-Armas R (2019) The influence of zooplankton communities on the feeding behavior of whale shark in Bahia de La Paz, Gulf of California. Revista Mexicana de Biodiversidad 91 (2020): e913054.

https://doi.org/10.22201/ib.20078706e.2020.91.3054

32. Wright SL, Thompson RC, Galloway TS (2013) The physical impacts of microplastics on marine organisms: A review. Environ Poll 178 483-492. https://doi.org/10.1016/j.envpol.2013.02.031

33. Zhang C, Chen X, Wang J, Tan L (2017) Toxic effects of microplastic on marine microalgae Skeletonema costatum: Interactions between microplastic and algae, Environ Pollut 220 B, 12821288. https://doi.org/10.1016/j.envpol.2016.11.005

\section{Figures}
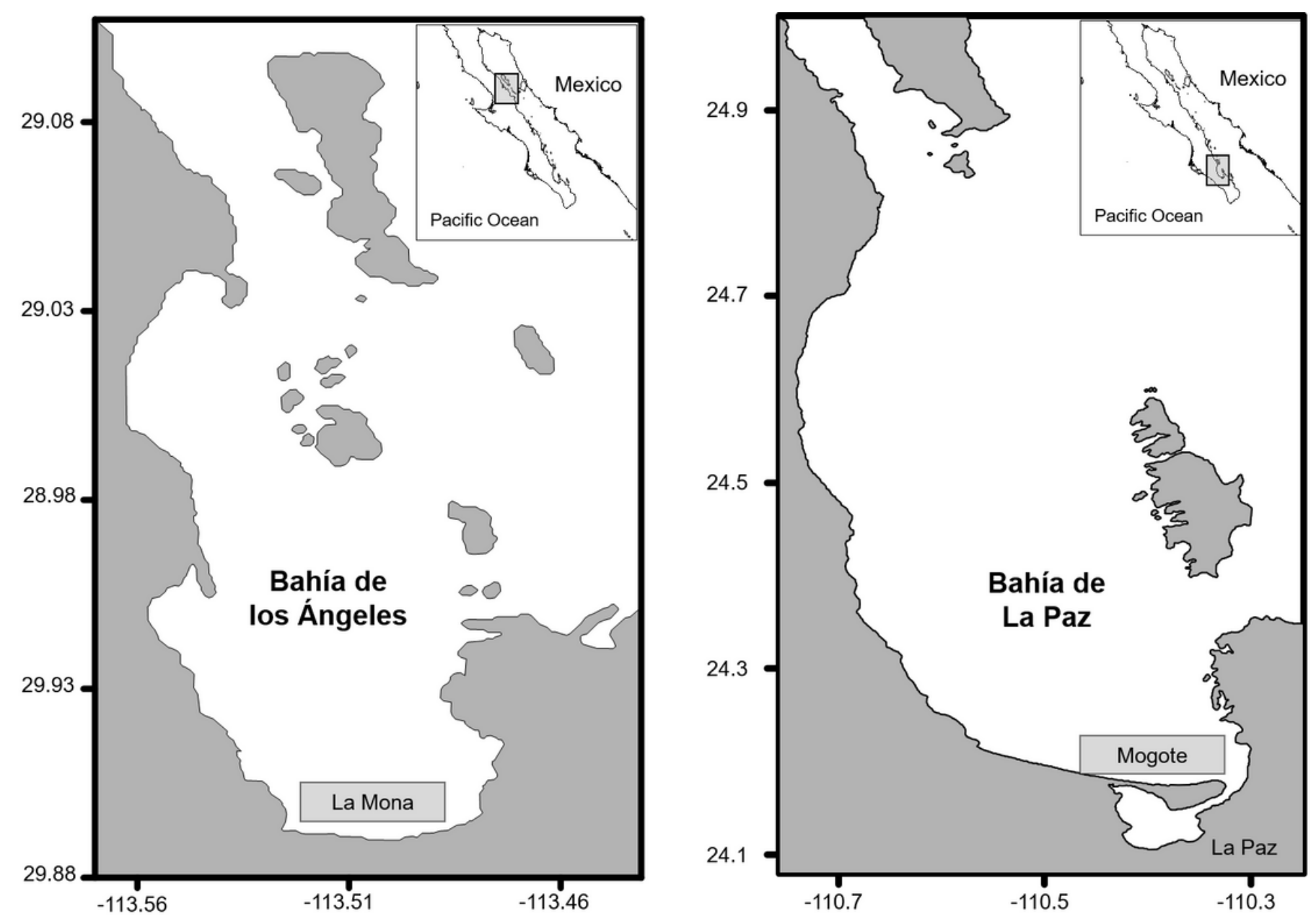

Figure 1 
Map of the study area: Bahía de los Angeles (BLA) and Bahía de La Paz (LAP), Mexico. Grey boxes indicate sampling areas. Map designed with Surfer Plot program. Note: The designations employed and the presentation of the material on this map do not imply the expression of any opinion whatsoever on the part of Research Square concerning the legal status of any country, territory, city or area or of its authorities, or concerning the delimitation of its frontiers or boundaries. This map has been provided by the authors.

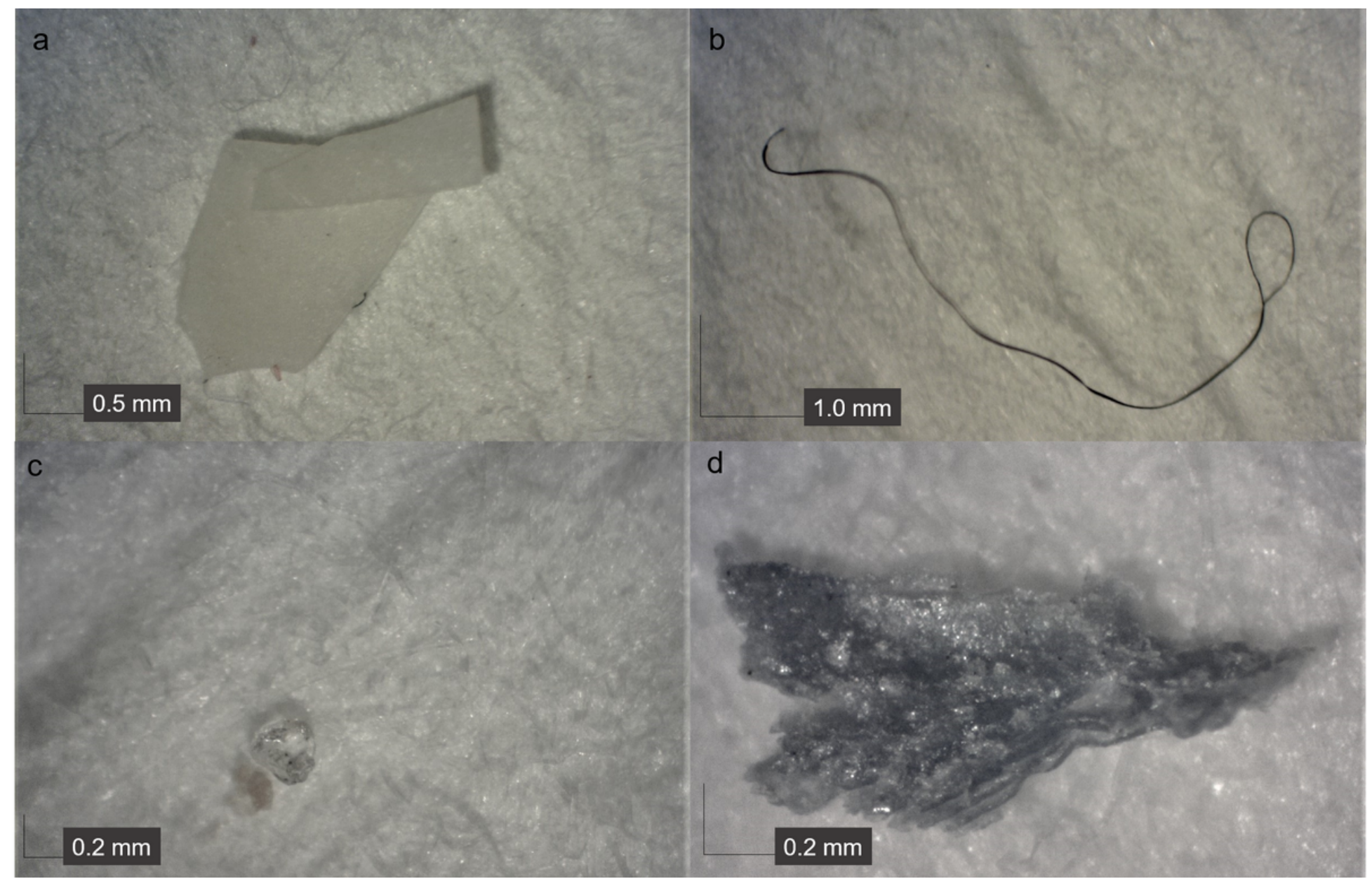

\section{Figure 2}

Images of microplastics types: fragment (a), line (b), pellet (c) and film (d) found in water samples from the whale shark feeding area in La Paz bay. 


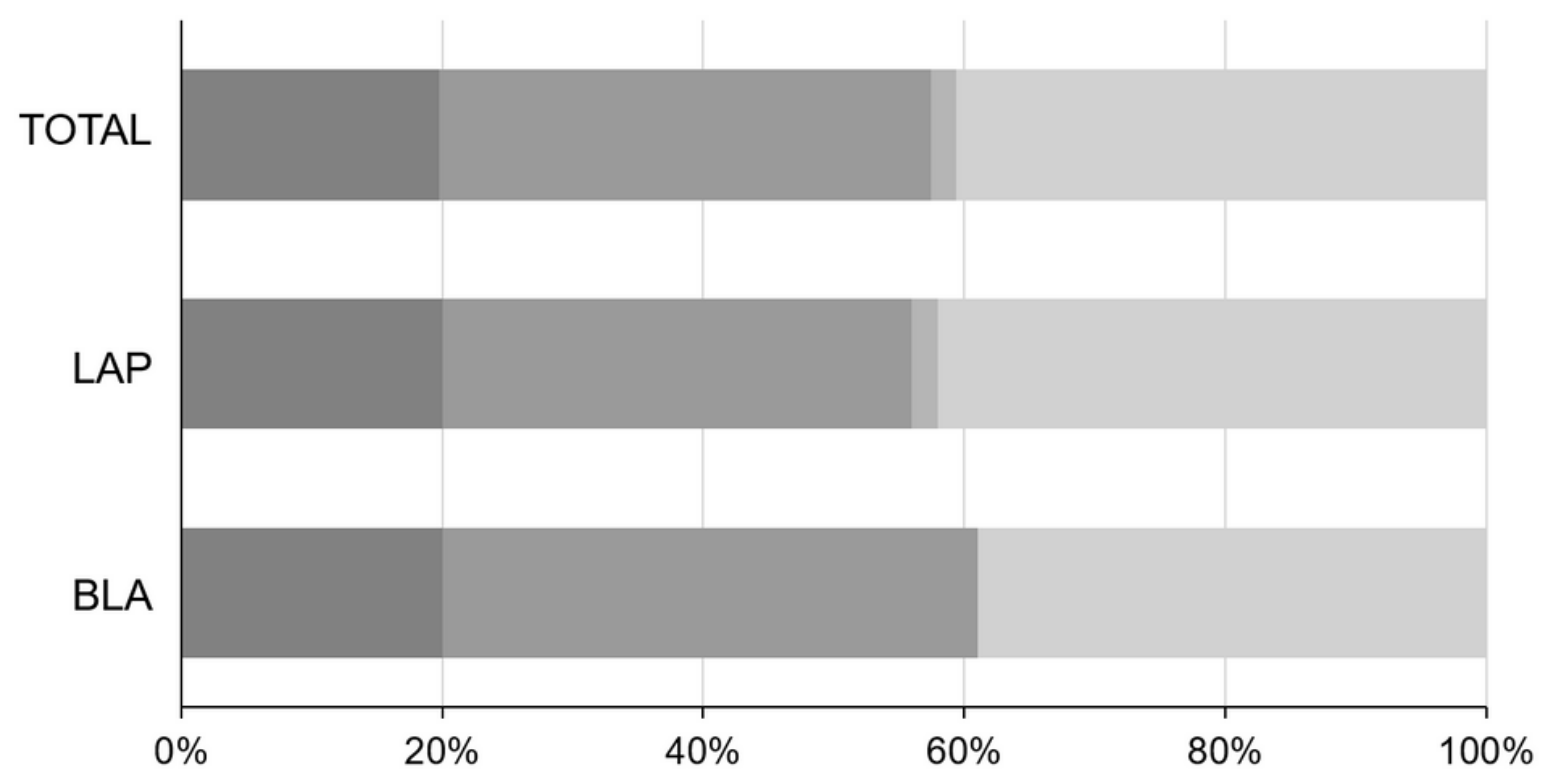

- FRAGMENT - LINE

PELLET

FILM

Figure 3

Percentage of fragment, line, pellet, and film found in water samples collected in Bahía de los Angeles, Bahía de La Paz and in total. 